\title{
Pain intensity assessment in chronic renal patients on hemodialysis
}

\author{
Avaliação da intensidade da dor de pacientes renais crônicos em tratamento hemodialítico \\ Veronius da Rosa Marques ${ }^{1}$, Priscila Escobar Benetti ${ }^{2}$, Eliane Raquel Rieth Benetti ${ }^{3}$, Cleci Lourdes Schimidt Piovesan \\ Rosanelli ${ }^{4}$, Christiane de Fátima Colet ${ }^{4}$, Eniva Miladi Fernandes Stumm ${ }^{4}$
}

DOI 10.5935/1806-0013.20160023

\section{ABSTRACT}

BACKGROUND AND OBJECTIVES: Chronic renal patients refer different types of pain, with variable intensity and location. So, this study aimed at assessing pain of chronic renal patients on hemodialysis.

METHODS: This is a transversal and analytical study carried out with 88 patients on hemodialysis in a Nephrology Unit of the Northwest region of Rio Grande do Sul. Data were collected from May to July 2014, by means of a Socio-Demographic/ Clinic Characterization Form and McGill Questionnaire, short form, and were analyzed by means of the Statistical Package for the Social Sciences.

RESULTS: From participants, 57.5\% were males, 58.11\% were married and $49.4 \%$ were elderly. As to pain intensity during session, $75 \%$ had no pain, followed by mild pain (17\%), moderate (4\%) and severe (3.4\%) pain. At the end of the session, $58 \%$ remained without pain; however approximate percentages of mild or moderate pain $(20.5 \%$ and $19.3 \%)$ and severe pain $(2.3 \%)$ have shown increased pain intensity during the course of hemodialysis.

CONCLUSION: Results are important as subsidies to qualify multiprofessional team actions toward attention to chronic renal patients and extensive to their families.

Keywords: Chronic renal disease, Chronic renal failure, Dialysis, Nursing, Pain, Patients.

1. Hospital de Caridade de Ijuí, Departamento de Enfermagem Assistencial da Unidade de Diálise, Ijuí, RS, Brasil.

2. Universidade Regional do Noroeste do Estado do Rio Grande do Sul, Faculdade de Enfermagem, Ijuí, RS, Brasil.

3. Universidade Federal de Santa Maria, Hospital Universitário de Santa Maria, Departamento de Enfermagem, Santa Maria, RS, Brasil.

4. Universidade Regional do Noroeste do Estado do Rio Grande do Sul, Ijuí, RS, Brasil.

Submitted in November 6, 2015.

Accepted for publication in April 18, 2016.

Conflict of interests: none - Sponsoring sources: none.

Correspondence to

Eniva Miladi Fernandes Stumm

Rua do Comércio, 300 - Departamento de Ciências da Vida

98700-000 Ijuí, RS, Brasil.

E-mail: eniva@unijui.edu.br

(C) Sociedade Brasileira para o Estudo da Dor

\section{RESUMO}

JUSTIFICATIVA E OBJETIVOS: $\mathrm{O}$ paciente renal crônico refere sentir diferentes tipos de dor, de intensidade e localização variáveis. Nesse sentido, este estudo objetivou analisar a dor de pacientes renais crônicos em tratamento hemodialítico.

MÉTODOS: Estudo transversal e analítico, realizado com 88 pacientes que faziam hemodiálise em Unidade Nefrológica do noroeste do Rio Grande do Sul. Os dados foram coletados de maio a julho de 2014, por meio de Formulário de Caracterização Sócio-Demográfica/Clínica e Questionário McGill, em sua forma reduzida e analisados por meio do Statistical Package for the Social Sciences.

RESULTADOS: Dos participantes, $57,5 \%$ eram homens, $58,11 \%$ casados, $49,4 \%$ idosos. Quanto à intensidade da dor presente durante a sessão, $75 \%$ não tiveram dor, seguidos de dor leve $(17 \%)$, moderada $(4 \%)$ e intensa $(3,4 \%)$. No final da hemodiálise, $58 \%$ continuavam sem dor, porém percentuais aproximados de dor leve ou moderada $(20,5 \%$ e $19,3 \%)$ e intensa $(2,3 \%)$, demonstraram aumento da intensidade da dor com o decorrer da hemodiálise.

CONCLUSÁO: Os resultados obtidos são importantes como subsídios para qualificar as ações da equipe multiprofissional, direcionadas à atençấo aos renais crônicos, extensivas aos seus familiares.

Descritores: Diálise, Doença renal crônica, Dor, Enfermagem, Insuficiência renal crônica, Pacientes.

\section{INTRODUCTION}

Chronic renal disease (CRD) is progressive, disabling and irreversible, affects millions of people of all racial and ethnic groups, has a high incidence, high morbidity and mortality rates and is a world health problem ${ }^{1}$. It is characterized by structural kidney abnormalities which may lead to renal function decrease, diagnosed by glomerular filtration rate below $60 \mathrm{~mL} / \mathrm{min} / 1.73 \mathrm{~m}^{2}$ for three months or longer ${ }^{1}$. Epidemiological data show that in Brazil, in the year 2000, there were 42695 patients on dialysis, 65121 in 2005, 91314 in 2011 and 100397 in 2013 and, from these, 12286 in the Southern region ${ }^{2}$.

Therapies for CRD are hemodialysis, peritoneal dialysis, continuous ambulatory peritoneal dialysis (CAPD), intermittent peritoneal dialysis (IPD), automated peritoneal dialysis (APD) and renal transplant. Hemodialysis improves survival, however it may trigger social isolation, movement and physical activity difficulties, loss of autonomy, changes 
in body image and feeling of imminent death ${ }^{3}$. Similarly, there are hemodialysis adverse effects, such as pain, catheter obstruction, accidental needle traction, malfunctioning of dialysis machine, rupture of lines and/or capillary fibers, allergy, hypotension and iatrogenesis during drug administration ${ }^{4}$.

Pain is more than a symptom; it is a sensation or experience, which may be associated to real or potential tissue injury, has a subjective and personal interpretation and involves sensory, affective, autonomic and behavioral aspects 5 . Pain results in biological and psychosocial changes and distress, which are reflected on sleep quality, work, ambulation, mood, concentration, family relations and sexual activity ${ }^{6}$. So, pain also induces physical limitations which impair daily life activities and negatively affect quality of life (QL).

Within this context, it is known that chronic renal patients refer different types of pain, with variable intensity and location. This complaint is associated to high incidence of bone disease, progressive loss of muscle mass, and incidence of disabling chronic diseases, such as diabetes mellitus, neurological diseases and vascular obstructions ${ }^{7}$. In addition, there might be painful hemodialysis-related intercurrences. Among most common painful sensations of hemodialysis patients, bone pain is frequently referred and results in physical limitations impairing daily life activities, with negative repercussions on $\mathrm{QL}^{6}$. Another frequent complication of hemodialysis is cramps, in general preceded by hypotension and which causes severe pain due to involuntary muscle contractures, predominantly on lower limbs during the second half of the hemodialysis session ${ }^{8}$. So, it is important that renal unit nurses help patients identifying types of pain, aiming at establishing pharmacological or non-pharmacological strategies for its relief.

Adequate pain intensity identification, by means of validated scales, and the evaluation and use of multimodal strategies for its relief permeate moral structure and ethic principles that support professional-patient relationships. Bioethics principles have to be respected during nursing assistance and should justify decisions and interventions aiming at painful patients' wellbeing and safety. This because if pain is not adequately evaluated and managed it may cause immediate organic and emotional injuries, such as hypoventilation, increased heart work, decreased peripheral perfusion, tachycardia and anxiety?

In light of the above, it is important that professionals working in dialysis units evaluate pain presence and intensity and involved subjective aspects, to institute timely management. In this sense, even being pain a common and clinically relevant experience in dialysis units, it has not been adequately appreciated, evaluated and treated in the clinical practice. So, we believe that this study might support nursing professionals in planning actions giving priority to pain evaluation and control in chronic renal patients on hemodialysis.

Based on these considerations, this study aimed at evaluating pain in chronic renal patients on hemodialysis.

\section{METHODS}

This is a transversal, analytical and quantitative study carried out in a Nephrology Unit of a general hospital of the Northwest region of Rio Grande do Sul, with 88 chronic renal patients on hemodialysis. Pain evaluation and control were not carried out in a systematized way in this unit. Participated in the study patients on hemodialysis for more than six months in the unit, and those with difficulty to understand questions of data collection tools were excluded. Data were collected from May to July 2014 by means of Socio-Demographic/Clinic Characterization Form and McGill Questionnaire (short form) ${ }^{10}$, as from individual interviews and search on participants' medical records. McGill questionnaire (short form) evaluates pain in three dimensions (sensory, affective and evaluative) as from words selected by patients to describe their pain. Sensory dimension includes words describing pain experience quality in terms of temporal, spacial, thermal pressure and other properties. Affective dimension includes words describing pain experience in terms of tension, fear and autonomic properties, and words included in the evaluative dimension describe subjective global pain intensity.

Patients were asked to indicate, among 20 groups of adjectives, those better describing their pain, and were oriented to use just one word per group. These adjectives reflect sensory (categories 1-10), affective (categories 11-15) and evaluative (category 16) dimensions of patients' pain. A mixed class of words (categories 17-20) has also been described.

\section{Statistical analysis}

After collection, data were stored in Excel for Windows and analyzed with the Statistical Package for the Social Sciences, version 18.0. Results are shown in tables.

This study is part of the inter-institutional research "Evaluation of pain, stress and coping in hospitalized patients and relatives". All ethic aspects ruling research with humans were respected, according to Resolution 466/12 of the Ministry of Health, project approved by the Research Ethics Committee, CAAE 20835613.6.0000.5350, Consolidated Opinion 427.613/2013. All patients were explained about the objectives of the research and have signed the Free and Informed Consent Term (FICT).

\section{RESULTS}

All participants (88) were submitted to hemodialysis three times a week. As to dialysis access, $84.1 \%$ had arteriovenous fistula (AVF) and $15.9 \%$ central double-lumen venous catheter (DLC). With regard to participants' baseline diseases, most common were diabetic nephropathy (25\%), hypertensive nephropathy $(20.05 \%)$ and polycystic kidneys (13.6\%). From participants, $61.4 \%$ did not practice any physical activity and $38.6 \%$ reported practicing, being hiking practiced by $88.2 \%$.

Table 1 shows patients' socio-demographic characteristics. 
Table 1. Patients' socio-demographic characteristics. ljuí, RS, 2014

\begin{tabular}{|c|c|c|c|}
\hline \multirow[t]{2}{*}{ Variables } & \multicolumn{2}{|c|}{ Gender } & \multirow{2}{*}{$\begin{array}{l}\text { Total } \\
\mathrm{n}(\%)\end{array}$} \\
\hline & $\begin{array}{c}\text { Female } \\
\mathrm{n}(\%)\end{array}$ & $\begin{array}{l}\text { Male } \\
\mathrm{n}(\%)\end{array}$ & \\
\hline $\begin{array}{l}\text { Age (years)* } \\
\text { Below } 40 \\
40 \text { to } 60 \\
\text { Above } 60\end{array}$ & $\begin{array}{c}5(5.7) \\
17(19.5) \\
15(17.2)\end{array}$ & $\begin{array}{c}4(4.6) \\
18(20.7) \\
28(32.2)\end{array}$ & $\begin{array}{c}9(10.3) \\
35(40.2) \\
43(49.4)\end{array}$ \\
\hline $\begin{array}{l}\text { Mean } \pm \text { SD } \\
\text { (Minimum;Maximum) }\end{array}$ & \multicolumn{3}{|c|}{$58.98 \pm 13.54(29 ; 89)$} \\
\hline $\begin{array}{l}\text { Live with } \\
\text { Relatives } \\
\text { Alone }\end{array}$ & $\begin{array}{c}31(35.2) \\
6(6.8)\end{array}$ & $\begin{array}{l}42(47.7) \\
9(10.2)\end{array}$ & $\begin{array}{l}73(83.0) \\
15(17.0)\end{array}$ \\
\hline $\begin{array}{l}\text { Marital status } \\
\text { Married } \\
\text { Single } \\
\text { Divorced/separate }\end{array}$ & $\begin{array}{c}16(18.2) \\
5(5.7) \\
4(4.5)\end{array}$ & $\begin{array}{c}35(39.8) \\
66.8) \\
6(6.8)\end{array}$ & $\begin{array}{l}51(58.0) \\
11(12.5) \\
10(11.4)\end{array}$ \\
\hline $\begin{array}{l}\text { Widow/er } \\
\text { Stable union }\end{array}$ & $\begin{array}{l}9(10.2) \\
3(3.4)\end{array}$ & $\begin{array}{l}11.1) \\
3(3.4)\end{array}$ & $\begin{aligned} 10 & (11.4) \\
6 & (6.8)\end{aligned}$ \\
\hline $\begin{array}{l}\text { Children* } \\
\text { Yes } \\
\text { No }\end{array}$ & $\begin{array}{c}32(36.8) \\
5(5.7)\end{array}$ & $\begin{array}{l}43(49.4) \\
7(8.0)\end{array}$ & $\begin{array}{l}75(86.2) \\
12(13.8)\end{array}$ \\
\hline Mean $\pm S D$ (Minimum;Maximum) & \multicolumn{3}{|c|}{$3.09 \pm 2.11(1 ; 11)$} \\
\hline $\begin{array}{l}\text { How many children } \\
\text { One } \\
\text { Two } \\
\text { Three } \\
\text { Four } \\
\text { Five or more }\end{array}$ & $\begin{array}{c}10(13.3) \\
4(5.3) \\
4(5.3) \\
6(8.0) \\
8(10.7)\end{array}$ & $\begin{array}{c}9(12.0) \\
11(14.7) \\
13(17.3) \\
6(8.0) \\
4(5.3)\end{array}$ & $\begin{array}{l}19(25.3) \\
15(20.0) \\
17(22.7) \\
12(16.0) \\
12(16.0)\end{array}$ \\
\hline $\begin{array}{l}\text { Education level }^{\star} \\
\text { Illiterate } \\
\text { Basic education } \\
\text { High school } \\
\text { Graduation } \\
\text { Post-graduation }\end{array}$ & $\begin{array}{c}2(2.3) \\
25(28.7) \\
7(8.0) \\
2(2.3) \\
1(1.1)\end{array}$ & $\begin{array}{c}2(2.3) \\
39(44.8) \\
8(9.2) \\
- \\
1(1.1)\end{array}$ & $\begin{array}{c}4(4.6) \\
64(73.6) \\
15(17.2) \\
2(2.3) \\
2(2.3)\end{array}$ \\
\hline $\begin{array}{l}\text { Religion } \\
\text { Catholic } \\
\text { Evangelist }\end{array}$ & $\begin{array}{l}21(23.9) \\
16(18.2)\end{array}$ & $\begin{array}{l}33(37.5) \\
18(20.5)\end{array}$ & $\begin{array}{l}54(61.4) \\
34(38.6)\end{array}$ \\
\hline $\begin{array}{l}\text { Income in reals }{ }^{* *} \\
\text { Less than } 1,000 \\
1,000 \text { to } 1,500 \\
1,500 \text { to } 2,000 \\
\text { More than } 2,000\end{array}$ & $\begin{array}{c}5(6.4) \\
18(23.1) \\
4(5.1) \\
6(7.7)\end{array}$ & $\begin{array}{c}14(17.9) \\
13(16.7) \\
6(7.7) \\
12(15.4)\end{array}$ & $\begin{array}{l}19(24.4) \\
31(39.7) \\
10(12.8) \\
18(23.1)\end{array}$ \\
\hline $\begin{array}{l}\text { Mean } \pm \text { SD } \\
\text { (Minimum;Maximum) }\end{array}$ & \multicolumn{3}{|c|}{$2.173 .02 \pm 2.446 .32(724 ; 20.000)$} \\
\hline $\begin{array}{l}\text { Profession - occupation } \\
\text { Retired } \\
\text { Rural worker } \\
\text { Sickness allowance } \\
\text { Urban worker } \\
\text { Housewife }\end{array}$ & $\begin{array}{c}13(14.8) \\
7(8.0) \\
8(9.1) \\
4(4.6) \\
5(5.7)\end{array}$ & $\begin{array}{c}23(26.1) \\
12(13.6) \\
9(10.2) \\
7(8.0) \\
-\end{array}$ & $\begin{array}{l}36(40.9) \\
19(21.6) \\
17(19.3) \\
11(12.6) \\
5(5.7)\end{array}$ \\
\hline Total & $37(42.0)$ & $51(58.0)$ & $88(100.0)$ \\
\hline
\end{tabular}

*1 no answer; ${ }^{*} 10$ no answer.

With regard to table 1 data, $58 \%$ were males, $58 \%$ were married, $49.4 \%$ were elderly with 1 to 3 children and have finished basic education. With regard to occupation, highest percentage was of retired, $40.9 \%$, followed by rural workers, $21.6 \%$. With regard to monthly income, it was observed that for virtually $40 \%$ it has varied from $1,000.00$ to $1,500.00$.
Table 2 shows different pain management modalities used by participants. It was observed that more than $40 \%$, including males and females, have referred using painkillers, followed by rest and massage, among other alternatives.

Table 2. Pain management modalities for chronic renal patients. ljuí, RS, 2014

\begin{tabular}{lccc}
\hline Type of management & \multicolumn{2}{c}{ Gender } & Total \\
& Female $n(\%)$ & Male $n(\%)$ & $n(\%)$ \\
\hline Pharmacological $(\mathrm{n}=88)$ & $22(25.0)$ & $19(21.5)$ & $41(46.5)$ \\
Massage $(\mathrm{n}=88)$ & $7(8.0)$ & $11(12.5)$ & $18(20.5)$ \\
Rest $(\mathrm{n}=88)$ & $9(10.2)$ & $10(11.4)$ & $19(21.6)$ \\
Others $(\mathrm{n}=88)$ & $10(11.4)$ & $9(10.2)$ & $19(21.6)$ \\
Tea $(\mathrm{n}=88)$ & $2(2.3)$ & - & $2(2.3)$ \\
\hline
\end{tabular}

Table 3 shows pain evaluation of chronic renal patients on hemodialysis, before, during and after hemodialysis sessions, according to gender, where it was observed that more than $50 \%$ of them have referred no pain before and after HD sessions and most of them have stated having no pain during the session.

Table 3. Pain intensity evaluation. ljuí, RS, 2014

\begin{tabular}{|c|c|c|c|c|}
\hline Intensity & & $\begin{array}{l}\text { Male } \\
\mathrm{n}(\%)\end{array}$ & $\begin{array}{c}\text { Female } \\
\mathrm{n}(\%)\end{array}$ & $\begin{array}{l}\text { Total } \\
\mathrm{n}(\%)\end{array}$ \\
\hline \multirow{4}{*}{$\begin{array}{l}\text { Pain evaluation } \\
\text { - before dialy- } \\
\text { sis }\end{array}$} & No pain & $36(40.9)$ & $21(23.9)$ & $57(64.8)$ \\
\hline & Mild & $8(9.1)$ & $6(6.8)$ & 14(15.9) \\
\hline & Moderate & $5(5.7)$ & $6(6.8)$ & 11(12.5) \\
\hline & Severe & $2(2.3)$ & $4(4.5)$ & $6(6.8)$ \\
\hline \multirow{4}{*}{$\begin{array}{l}\text { Pain evaluation } \\
\text { - during dialy- } \\
\text { sis }\end{array}$} & No pain & $40(45.5)$ & $26(29.5)$ & $66(75.0)$ \\
\hline & Mild & $7(8.0)$ & $8(9.1)$ & $15(17.0)$ \\
\hline & Moderate & $2(2.3)$ & $2(2.3)$ & $4(4.5)$ \\
\hline & Severe & $2(2.3)$ & $1(1.1)$ & $3(3.4)$ \\
\hline $\begin{array}{l}\text { Pain evaluation } \\
\text { - after dialysis }\end{array}$ & $\begin{array}{l}\text { No pain } \\
\text { Mild } \\
\text { Moderate } \\
\text { Severe }\end{array}$ & $\begin{array}{c}31(35.2) \\
9(10.2) \\
9(10.2) \\
2(2.3)\end{array}$ & $\begin{array}{c}20(22.7) \\
9(10.2) \\
8(9.1) \\
-\end{array}$ & $\begin{array}{c}51(58.0) \\
18(20.5) \\
17(19.3) \\
2(2.3)\end{array}$ \\
\hline \multirow{5}{*}{$\begin{array}{l}\text { Global pain ex- } \\
\text { perience evalu- } \\
\text { ation }\end{array}$} & No pain & $37(42.0)$ & 21(23.9) & $58(65.9)$ \\
\hline & Mild & $3(3.4)$ & $4(4.5)$ & $7(8.0)$ \\
\hline & Uncomfortable & $5(5.7)$ & $7(8.0)$ & 12(13.6) \\
\hline & Distressing & $3(3.4)$ & $2(2.3)$ & $5(5.7)$ \\
\hline & Terrible & $3(3.4)$ & $3(3.4)$ & $6(6.8)$ \\
\hline \multirow{5}{*}{$\begin{array}{l}\text { Global pain ex- } \\
\text { perience inten- } \\
\text { sity evaluation } \\
\text { (VAS) }\end{array}$} & No pain & $37(42.0)$ & 21(23.9) & $58(65.9)$ \\
\hline & Mild & $3(3.4)$ & $4(4.5)$ & $7(8.0)$ \\
\hline & Uncomfortable & $5(5.7)$ & $7(8.0)$ & 12(13.6) \\
\hline & Distressing & $3(3.4)$ & $2(2.3)$ & $5(5.7)$ \\
\hline & Terrible & $3(3.4)$ & $3(3.4)$ & $6(6.8)$ \\
\hline Total & & $51(58.0)$ & $37(42.0)$ & $88(100)$ \\
\hline
\end{tabular}

VAS = visual analog scale

Still with regard to table 3 data, among patients referring mild pain, the number of males and females was similar be- 
fore, during and after the HD session, however moderate pain complaints were more common before and after session, in a larger number of females before and males after session.

As to global evaluation of pain experience and pain intensity referred by respondents, a larger number of males have stated feeling no pain $(42 \%)$, followed by females $(23.9 \%)$. As to pain classification as uncomfortable, more females had this complaint as compared to males. Both male and female participants have referred in similar numbers feeling mild and distressing pain; just $3.4 \%$ of both males and females have referred horrible pain.

Table 4 shows the correlation of pain intensity evaluation by patients before, during and after hemodialysis and shows a strong correlation among their answers during session, after session and at global pain evaluation.

Table 4. Correlation of pain intensity evaluation. ljuí, RS, 2014

\begin{tabular}{lcccc}
\hline Evaluation periods & & & & \\
\hline Pre-dialysis & 1 & $0.370^{\star \star}$ & $0.367^{\star \star}$ & $0.913^{\star \star}$ \\
During dialysis & & 1 & $0.234^{\star}$ & $0.404^{\star *}$ \\
Post-dialysis & & & 1 & $0.415^{\star \star}$ \\
Global & & & & 1 \\
\hline
\end{tabular}

*Significant correlation $p<0.05$; * Significant correlation $p<0.01$.

Table 5 shows descriptive statistics of participants' pain estimate indices. It was observed that mean was higher for the sensitive index, with high standard deviation and variation coefficients, showing the subjectivity of issues involving pain.

Table 5. Descriptive statistics of pain estimate indices. ljuí, RS, 2014

\begin{tabular}{lccccc}
\hline $\begin{array}{l}\text { Pain estimate } \\
\text { indices }\end{array}$ & LL & UL & Mean & $\begin{array}{c}\text { Standard } \\
\text { Deviation }\end{array}$ & $\begin{array}{c}\text { Variation } \\
\text { coefficient (\%) }\end{array}$ \\
\hline Sensitive & 0 & 14 & 2.45 & 4.07 & 166.12 \\
Affective & 0 & 11 & 1.32 & 2.44 & 184.85 \\
Total & 0 & 25 & 3.77 & 6.40 & 169.76 \\
\hline
\end{tabular}

$\mathrm{LL}$ = lower limit; UL = upper limit.

Score: Pain Estimate Indices - Sensitive (0-33 points); Pain Estimate Indices Affective (0-12 points); Pain Estimate Indices - Total (0-45 points).

\section{DISCUSSION}

Male gender was predominant among research participants, confirming a study by the Hemodialysis Unit of a size IV public hospital of the city of Fortaleza/CE ${ }^{11}$ and confirmed by epidemiologic estimates of renal disease incidence. As to participants' age, $49.4 \%$ were elderly and this is also in line with Brazilian Society of Nephrology data which show that among patients on hemodialysis in 2013,31.4\% had more than 65 years of age ${ }^{2}$. It is thought that this high incidence of CRD is related to the fact that with age there is progressive physiological renal reserve loss, as a consequence of renal anatomic and functional changes.

Most participants lived with companion, were married and had children. Similar result was obtained by research developed by the Nephrology Unit of a size IV hospital where 77 patients were submitted to hemodialysis ${ }^{12}$. This result shows that patients may count on family support aiming at better coping with chronic disease, being aware that family presence and support may minimize possible physical, emotional and socio-economic injuries caused by chronic disease.

With regard to education, patients have attended few years of school. In this sense, it is assumed that low education level is a factor favoring social vulnerability and which may impair health care and patients' adhesion to therapy. So, it is important for nurses to know chronic renal patients' education level to adopt adequate approaches aiming at better adhesion to therapy.

All participants had religious beliefs. Religion, spirituality, faith in God, are emphasized in issues involving healthcare and are perceived as a way to explain life, with expectations in harmony to better cope with chronic diseases ${ }^{13}$.

Respondents' characterization with regard to time on hemodialysis shows mildly increased percentages of those between 30 and 60 months on HD. As from these data, it is considered that hemodialysis is a treatment modality benefiting chronic renal patients and contributing to increase life expectation with quality.

It was observed that more than $40 \%$ of patients used painkillers and this result shows the importance of nurses being alert to pain complaints, added to evaluation and monitoring with adequate tools. In this sense, it is important to adequately select patients under opioids for long periods to evaluate adverse effects, to adjust the dose, and to observe the need for drug withdrawal or replacement and monitoring ${ }^{14}$. In addition, the need to pay attention to and to appreciate pain complaints of chronic renal patients is emphasized, as well as its adequate management ${ }^{7}$. In this sense, pain measurement and evaluation scales are a mandatory strategy which favors assistance planning and nurses' decision making aiming at holistic assistance.

The fact that half of participants have not referred pain is in line with a study stating that care quality is a challenge for nursing, in the sense of building knowledge for hemodialysis patients to understand that their situation is identified by the nursing team and that other team members are committed and skilled for their integral and humanized care ${ }^{15}$.

Our study has observed that mild pain was more common among patients and percentages of males and females were similar before, during and after session; however, moderate pain complaints were more common before and after session, in higher percentages for females before and males after session, with unexpressive percentage of distressing pain (3.4\%). Results also show that among chronic renal patients, females feel more pain as compared to males and that painful patients in general are worried and fearful which may evolve to muscle tension, thus worsening pain ${ }^{6}$.

Our results show how important it is to the team to understand pain pathophysiology, clinical manifestations, types and characteristics as parameters for clinical evaluation, added to adequate management to minimize and/or exclude pain-triggering stimulations. One has to highlight the role of the nursing team with regard to patient care during painful procedures. 
Results regarding pain during hemodialysis show that even with dialysis technological advances, the incorporation of new techniques and new knowledge, hemodialysis patients' pain is still common and frequent ${ }^{7}$, so it is necessary attention to pain manifestations by this group of patients, with the institution of new procedures for their management.

The analysis of this research data, added to authors' opinions, shows how much it is necessary to advance in terms of actions aiming at adequate monitoring of situations involving pain in chronic renal patients undergoing hemodialysis. In this sense, nurses, for remaining longer with patients, may easily do so, using validated tools and this way evaluating pain and adequately treating it.

\section{CONCLUSION}

The study has provided the characterization of chronic renal patients on dialysis and the evaluation of pain intensity by means of a validated tool. Socio-demographic and clinical data are important because they favor team planning aiming at actions to meet their patients' needs and this way to qualify assistance.

Pain intensity evaluation reflects the importance of having adequate pain monitoring by the team in charge, with emphasis on nurses, since patients' arrival to the unit until discharge. Monitoring may be easily achieved with a validated tool, however it is necessary to previously prepare caregivers for this practice to be incorporated to daily activities of a Nephrology Unit so that pain is evaluated as the fifth vital sign. One has to stress the need for integrated work with the multiprofessional team involving nurse, physician, pharmacist, psychologist, dietician, physiotherapist and social worker, among others.
Our results may be important as subsidies for the implementation in nephrology units of the pain validation scale before, during and after hemodialysis sessions aiming at qualifying nursing assistance.

\section{REFERENCES}

1. National Kidney Foundation. KDOQI Clinical Practice Guideline for Diabetes and CKD: 2012 update. Am J Kidney Dis. 2012;60(5):850-86.

2. Sociedade Brasileira de Nefrologia. Censo de Diálise SBN 2013. [Internet]. Disponível em: http://www.sbn.org.br/pdf/censo_2013-14-05.pdf

3. Davison SN. End-of-life preferences and needs: perceptions of patients with chronic kidney disease. Clin J Am Soc Nephrol. 2010;5(2):195-204.

4. de Sousa MR, Silva AE, Bezerra AL, de Freitas JS, Miasso AI. [Adverse events in hemodialysis: reports of nursing professional]. Rev Esc Enferm USP. 2013;47(1):76-83. Portuguese.

5. Silva JA, Ribeiro-Filho NP. A dor como um problema psicofísico. Rev Dor 2011;12(2):138-51.

6. Silva FS, Pinheiro MS, França RC, Mendonça AE, Simpson CA, Leite EM. Evaluation of bone pain in patients with renal chronic with mineral disorder. J Nurse UFPE. 2013;7(5):1406-11.

7. Silva L, Mendonça AT, Carvalho LA. As características da dor em portadores de insuficiência renal crônica em programa de hemodiálise. Rev Univ Vale Rio Verde. 2013;10(1):590-9.

8. Frazão CM, Medeiros AB, Silva FB, Sá JD, Lira AL. Nursing diagnoses in chronic renal failure patients on hemodialysis. Acta Paul Enferm. 2014;27(1):40-3.

9. Magalhães PA, Mota FA, Saleh CM, Secco LM, Fusco SR, Gouvêa AG. Percepção dos profissionais de enfermagem frente à identificaçáo, quantificaçáo e tratamento da dor em pacientes de uma unidade de terapia intensiva de trauma. Rev Dor. 2011;12(3):221-5.

10. Melzak R. The short-form McGill pain questionnaire. Pain. 1987;30(2):191-7.

11. Madeiro AC, Machado PD, Bonfim IM, Braqueais AR, Lima F. Adesão de portadores de insuficiência renal crônica ao tratamento de hemodiálise. Acta Paul Enferm. 2010;23(4):546-51.

12. Patat CL, Stumm EM, Kirchner RM, Guido LA, Barbosa DA. Análise da qualidade e vida de usuários em hemodiálise. Enferm Global. 2012;11(27):66-76.

13. Valcanti CC, Chaves Ede C, Mesquita AC, Nogueira DA, de Carvalho EC. [Religious/spiritual coping in people with chronic kidney disease undergoing hemodialysis]. Rev Esc Enferm USP. 2012;46(4):838-45. Portuguese.

14. Kraychete DC, Siqueira JT, Garcia JB. Recomendaçóes para uso de opioides no Brasil: parte I. Rev Dor. 2013;14(4):295-30.

15. Quintana JM, Hammerschmidt KS, Santos SS. Percepçóes de idosos que vivenciam o cuidado de enfermagem durante a hemodiálise. Rev Eletr Enf. 2014;16(3):662-70. 